\section{Diterminasi Tipe Pelarut dan Proses Ekstraksi untuk Efektifitas dan Selektifitas Produksi Ekstrak Kaya Polifenol dari Euphorbia supina}

\section{Agung Nugroho}

Program Studi Teknologi Industri Pertanian, Bidang Teknologi Proses Bahan Alam, Universitas Lambung Mangkurat

anugroho@ulm.ac.id
Polifenol, terutama bioflavonoid sedang menjadi tren dunia dalam riset pengembangan produk terutama pada industri pangan fungsional, suplemen, dan kosmetika. Keunggulan polifenol terletak pada potensinya sebagai antioksidan melalui beberapa mekanisme penangkapan radikal bebas. Peran polifenol sangat penting dalam mencegah berbagai potensi penyakit degeneratif karena perubahan pola hidup masyarakat modern. Produksi ekstrak kaya polifenol dari Euphorbia supina masih belum banyak dikembangkan, sementara itu potensi pasar dan pengembangannya cukup besar. Penelitian ini bertujuan untuk menentukan tipe pelarut dan tipe proses ekstraksi yang efektif dan selektif dalam memproduksi ekstrak kaya polifenol dari E. supina. Lima jenis pelarut (MeOH, EtOH, 7o\% MeOH, 30\% $\mathrm{MeOH}$, dan $\mathrm{H}_{2} \mathrm{O}$ ) serta dua metode ekstraksi (ultrasonikasi dan refluks) diuji dalam penelitian ini. Metode ekstraksi refluks dengan pelarut EtOH mampu memberikan kinerja ekstraksi yang lebih baik ditinjau dari aspek efektifitas, efisiensi, selektifitas, serta aspek toksisitas dan lingkungan. Metode refluks menunjukkan efektifitas dua kali lebih baik dibanding ultrasonikasi.

Kata kunci: Euphorbia supina, efektivitas, selektifitas, ekstraksi, polifenol

Diajukan: 2 Juli 2019

Direvisi: 10 Juli 2019

Diterima: 18 Juli 2019

Dipublikasikan online: 20 Juli 2019

\section{Pendahuluan}

Senyawa polifenol telah menarik perhatian riset dunia dalam beberapa dasarwarsa terakhir ini, karena aktivitasnya sebagai antioksidan yang kuat dan aman. Sebagai antioksidan, polifenol bekerja melalui beberapa mekanisme yaitu melalu penangkapan radikal bebas, penghambat peroksidasi lipid, pemutus reaksi oksidasi dengan mengikat radikal bebas, serta sebagai pengikat (chelator) ion logam yang menggangu proses oksidasi (Hong et al., 2013). Flavonoid dan asam fenolik merupakan dua golongan polifenol yang terkenal dan keberadaannya pada bahan alam lebih dominan dibanding komponen lain (Nugroho, 2013). Beberapa studi telah membuktikan kekuatan aktivitas antioksidan flavonoid dibandingkan asam askorbat (vitamin C) sebagai antioksidan yang paling dikenal. Menggunakan metode DPPH, Hong et al. (2013), Liu et al. (2009), dan Braca et al. (2002) melaporkan bahwa aktivitas flavonoid (quercitrin) lebih kuat 1,5 kali lipat daripada asam askorbat.

Potensi polifenol terletak pada kekuatan aktivitas antioksidannya yang merupakan output kinerja simultan dari beberapa gugus fungsional yang pada strukturnya serta kelebihan pada aspek keamanan sebagai komponen aktif untuk fungsi pangan fungsional (Babujanarthanam et al., 2010). Pada umumnya, flavonoid pada bahan alam tersimpan pada formasi glikosidanya. Menurut Camalada et al. (2005), kelebihan glikosida polifenol dibandingkan dengan aglikonnya, terletak pada kekuatan aktivitas antioksidan secara in vivo serta ketahanan strukturnya untuk mencapai bagian akhir dari usus halus, di mana hal ini penting pada mekanisme fisiologis tubuh manusia.

Euphorbia supina. merupakan tanaman perdu semusim dari keluarga Euphorbiaceae. Sebagai ciri utama adalah batang dan daunnya yang berwarna hijau keunguan dan bergetah (Huang et al., 2012). Polifenol (flavonoid dan asam fenolik) merupakan senyawa penciri dari beberapa keluarga Euphobiaceae (Farmakope Indonesia, 2014) yang keberadaannya lebih dominan dibanding senyawa metabolit sekunder lainnya. Produksi ekstrak kaya polifenol dari E. supina memiliki potensi untuk dikembangkan secara komersial sebagai diversifikasi produk suplemen sumber antioksidan.

Harga polifenol, terutama flavonoid murni di pasaran dunia masih sangat tinggi. Untuk pengembangan polifenol sebagai produk suplemen dalam industri pangan fungsional memerlukan kelayakan bisnis di mana harga bahan baku dan proses produksi menjadi faktor penting. Untuk itu perlu pengembangan teknologi proses ekstraksi yang efektif, selektif, dan efisien dengan sumber bahan baku yang murah sehingga mampu menurunkan biaya produksi.

Cara mensitasi artikel ini:

Nugroho, A (2019) Diterminasi Tipe Pelarut dan Proses Ekstraksi untuk Efektifitas dan Selektifitas Produksi Ekstrak Kaya Polifenol dari Euphorbia supina. Buletin Profesi Insinyur 2(1) 007-011 
Bertolak dari masalah tersebut, penelitian ini menguji beberapa tipe pelarut $(\mathrm{MeOH}, \mathrm{EtOH}, 70 \% \mathrm{MeOH}, 30 \%$ $\mathrm{MeOH}$, dan $\mathrm{H}_{2} \mathrm{O}$ ) dan dua proses ekstraksi (ultrasonikasi dan refluks) yang mampu menghasilkan kinerja yang lebih efektif, selektif, dan efisien dalam produksi ekstrak kaya polifenol dari tanaman E. supina.

\section{Metodologi}

Bagian tanaman selain akar dari E. supina (Gambar 1) dikeringanginkan pada suhu ruang selama 5 hari dilanjutkan pengeringan oven pada suhu $40^{\circ} \mathrm{C}$, selama 5 jam bertujuan untuk menyeragamkan kadar air sampel. Sampel kering dihancurkan menggunakan blender untuk memperluas bidang permukaan dan menyeragamkan ukuran. Ekstraksi dilakukan dengan metode ultrasonikasi dan refluks pada suhu $75^{\circ} \mathrm{C}$ selama 4 jam, di mana setiap perlakuan menggunakan $20 \mathrm{~g}$ sampel kering pada $200 \mathrm{ml}$ pelarut.

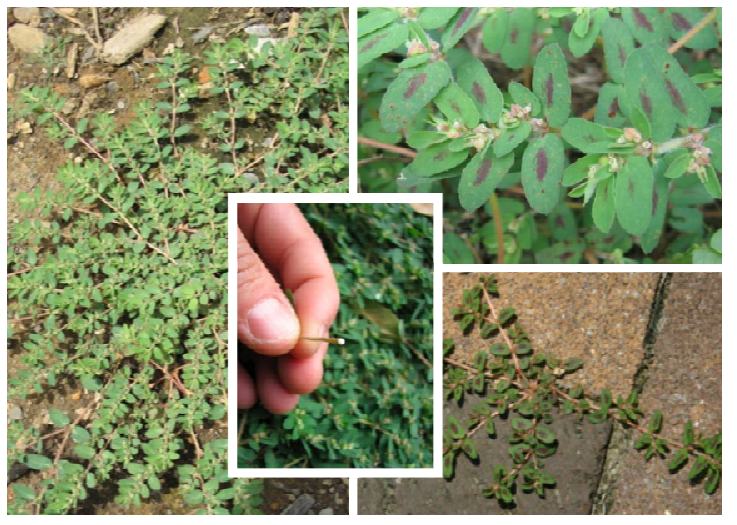

Gambar 1 Morfologi tanaman Euphorbia supina.

Jenis pelarut sebagai variabel bebas terdiri dari lima jenis perlakuan, yaitu $\mathrm{MeOH}, \mathrm{EtOH}, 70 \% \mathrm{MeOH}$, $30 \% \mathrm{MeOH}$, dan $\mathrm{H}_{2} \mathrm{O}$. Sementara itu pengujian dengan metode refluks dilakukan dengan pelarut $\mathrm{MeOH}$. Ekstrak dalam bentuk solid diperoleh dengan mengevaporasikan ekstrak cair yang telah disaring dengan kertas saring pada rotary vacuum evaporator yang dilanjutkan pengeringan menggunakan sebuah freeze dryer. Ekstrak pada selanjutnya dilarutkan dengan metanol untuk menghasilkan larutan 5000 ppm, yang digunakan untuk analisis kuantitatif.

Analisis kuantitatif dilakukan menggunakan High Performance Liquid Chromatography (HPLC). Instrumen HPLC yang digunakan adalah sebuah Varian HPLC yang terdiri dari dua buah pompa Prostar 210, sebuah UV-Vis detector Prostar 325, sebuah kolom kromatografi dari Shiseido (Tokyo, Japan) Capcell PAK C18 column (5 $\mu \mathrm{m}, 4.6 \mathrm{~mm} \times 250 \mathrm{~mm}$ ) beserta pengendali temperaturnya. Data yang dihasilkan dikoleksi dan diolah menggunakan Varian Star Workstation. Pelarut A adalah air dengan $0.05 \%$ asam asetat dan Pelarut $\mathrm{B}$ adalah metanol: $\mathrm{CH}_{3} \mathrm{CN}$ dengan rasio 60:40 (HPLC grade, J.T.Baker, USA).

Elusi gradien dari fase gerak diprogram mengikuti referensi oleh Nugroho et al. (2013) dengan prosedur sebagai berikut $(A) /(B)=85 / 15$ (menit ke-0) $\rightarrow 35 / 65$ (menit ke-45) $\rightarrow$ 10/90 (menit ke-46, dan statis sampai menit ke-50) $\rightarrow$ 85/15 (menit ke52, dan dilanjutkan fase statis selama 3 menit untuk pencucian kolom). Kecepatan alir sebesar $1 \mathrm{ml} /$ menit. UV detektor dimonitor pada panjang gelombang $254 \mathrm{~nm}$ dan direkam selama 40 menit pada temperatur $40^{\circ} \mathrm{C}$.

Stok larutan standar delapan komponen kelompok polifenol (gallic acid, methyl gallate, avicularin, astragalin, juglanin, isoquercitrin 6"'-gallate, astragalin 6"-gallate, dan ellagic acid) disiapkan dengan konsentrasi 1000 ppm dengan melarutkan delapan komponen standar tersebut dengan metanol. Kurva kalibrasi diperoleh dengan pengukuran area puncak dari enam konsentrasi serial yang dikorelasikan dengan konsentrasi masing-masing dari delapan komponen standar. Larutan standar dan larutan sampel difiltrasi menggunakan syringe filter unit $(0.50 \mu \mathrm{m}$, Dismic-25JP Advantec, Japan) sebelum diinjeksi ke dalam HPLC.

\section{Hasil dan Pembahasan}

\section{Linearitas, LOD dan LOQ}

Persamaan regresi linear diperlukan untuk menentukan konsentrasi senyawa yang dianalisis menggunakan HPLC. Persamaan regresi dari delapan komponen polifenol yang dianalisis beserta nilai linearitasnya ditentukan dengan menentukan luas area dari enam tingkat konsentrasi bertingkat mulai dari 3,91 ppm - 125 ppm yang merupakan hasil pengenceran dari stok larutan standar yang telah dibuat sebelumnya. Tingkat konsentrasi terkecil ditentukan dari nilai Limit of Quantitation (LOQ) yaitu sebesar 0,44 , sementara itu Limit of Detection (LOD) diperoleh angka sebesar 0,13. Nilai linearitas diperoleh angka lebih dari 0,999 yang berarti bahwa proses penentuan persamaan regresi memiliki kesetaraan yang tinggi. Persamaan regresi linear yang yang menunjukkan hubungan antara konsentrasi polifenol dengan luas puncak pada kromatogram HPLC yang dihasilkan pada panjang gelombang $254 \mathrm{~nm}$ ditunjukkan pada Tabel 1.

Tabel 1. Linearitas dari kurva standar delapan komponen polifenol serta nilai LOD dan LOQ

\begin{tabular}{cccccc}
\hline $\begin{array}{c}\text { No. } \\
\text { Komp. }\end{array}$ & $\begin{array}{c}\text { Persamaan } \\
\text { Linear }\end{array}$ & $\begin{array}{c}\text { Rentang } \\
(\mu \mathrm{g} / \mathrm{ml})\end{array}$ & $\mathrm{R}^{2}$ & $\begin{array}{c}\text { LOD } \\
(\mu \mathrm{g} / \mathrm{ml})\end{array}$ & $\begin{array}{c}\text { LOQ } \\
(\mu \mathrm{g} / \mathrm{ml})\end{array}$ \\
\hline $\mathbf{1}$ & $y=145.021 x+33.587$ & $1.56-50.00$ & 0.9997 & 0.80 & 2.68 \\
$\mathbf{2}$ & $y=228.517 x+56.229$ & $1.56-50.00$ & 0.9997 & 0.41 & 1.37 \\
$\mathbf{3}$ & $y=170.598 x+42.468$ & $1.56-50.00$ & 0.9999 & 0.63 & 2.10 \\
$\mathbf{4}$ & $y=589.979 x+72.816$ & $1.56-50.00$ & 0.9998 & 0.13 & 0.44 \\
$\mathbf{5}$ & $y=255.632 x+54.871$ & $1.56-50.00$ & 0.9999 & 0.37 & 1.24 \\
$\mathbf{6}$ & $y=247.289 x+65.751$ & $1.56-50.00$ & 0.9999 & 0.34 & 1.14 \\
$\mathbf{7}$ & $y=460.649 x+65.398$ & $1.56-50.00$ & 0.9999 & 0.18 & 0.61 \\
$\mathbf{8}$ & $y=182.691 x+58.731$ & $1.56-50.00$ & 0.9998 & 0.50 & 1.67 \\
\hline
\end{tabular}

Keterangan nomor komponen polifenol: 1: gallic acid; 2: methyl gallate; 3: avicularin; 4: astragalin; 5: juglanin; 6: isoquercitrin 6"gallate; 7: astragalin 6"'-gallate; dan 8: ellagic acid. 


\section{Pengaruh tipe pelarut dan metode ekstraksi terhadap konsentrasi polifenol}

Pengaruh jenis pelarut dan tipe proses ekstraksi terhadap konsentrasi polifenol pada ekstrak dan sampel kering $E$. supina ditentukan dengan mengetahui luas daerah puncak dari tujuh kromatogram ekstrak pada konsentrasi masing-masing 5000 ppm. Secara keseluruhan, ada enam jenis ekstrak yang diuji. Lima ekstrak untuk menentukan jenis pelarut yang efektif dan selektif dalam mengekstrak polifenol pada E. Supina yang terdiri dari ekstrak $\mathrm{MeOH}, \mathrm{EtOH}, 70 \% \mathrm{MeOH}, 30 \% \mathrm{MeOH}$, dan $\mathrm{H} 2 \mathrm{O}$. Sementara itu untuk menentukan tipe ekstraksi yang efektif diuji dua tipe proses ekstraksi, yaitu metode ultrasonikasi dan refluks, di mana untuk keduanya digunakan pelarut yang sama yaitu $\mathrm{MeOH}$. Penggunaan pelarut polar tersebut didasarkan pada struktur kimia polifenol teridentifikasi yang bersifat polar ke semi polar berkat kehadiran beberapa gugus hidroksida yang melimpah serta beberapa glikosida seperti terlihat pada Gambar 2.

Konsentrasi polifenol pada masing-masing ekstrak dapat diketahui berdasarkan luas daerah puncak dari delapan komponen yang muncul pada waktu retensi yang sama dengan waktu retensi komponen standar. Gambar 3 menyajikan kromatogram dan posisi (retention time, Rf) dari delapan komponen standar serta komponen yang terdeteksi pada ekstrak $\mathrm{MeOH}$. Mengingat jenis kolom yang digunakan pada analisis HPLC adalah C-18 ODS (octadecylsilane) yang bersifat non polar, maka komponen dengan polaritas yang lebih tinggi akan muncul lebih awal atau memiliki nilai Rf yang lebih kecil. Sebaliknya, komponen dengan polaritas lebih rendah akan terelusi secara lebih lambat. Terlihat bahwa asam fenolik sederhana dengan bobot molekul rendah seperti gallic acid dan methyl gallate muncul lebih awal. Sementara itu, flavonoid glikosida dengan struktur kimia yang lebih kompleks serta bobot molekul yang lebih besar, seperti ellagic acid dan beberapa flavonoid glikosida akan muncul pada $\mathrm{Rf}$ yang lebih besar.

Untuk mengetahui pengaruh jenis pelarut serta efektifitas dan selektifitasnya terhadap konsentrasi delapan komponen polifenol pada lima jenis ekstrak yang berbeda jenis pelarutnya, analisis kuantitatif menggunakan metode HPLC dilakukan berdasarkan persamaan regresi linear yang telah ditentukan sebelumnya (Tabel 1). Tabel 2 menyajikan hasil analisis kuantitatif dari delapan komponen polifenol yang diperoleh dari rerata tiga kali pengulangan. Sementara Tabel 3 menyajikan perbedaan efektifitas proses ekstraksi antara metode ultrasonikasi dengan metode refluks.

Terlihat pada Tabel 2, semakin tinggi konsentrasi $\mathrm{H}_{2} \mathrm{O}$, semakin tinggi pula konsentrasi total dari golongan asam fenolik sederhana. Sebaliknya, semakin tinggi kadar $\mathrm{MeOH}$ atau EtOH dari pelarut, maka golongan flavonoid glikosida dan asam fenolik komplek lebih banyak yang terekstrak. $\mathrm{MeOH}$ dan EtOH memiliki indeks polaritas relatif berturut terhadap air (polaritas relatif: 1) sebesar 0,762 dan 0,654 (Smallwood, 1996). Perbedaan indeks polaritas memperlihatkan daya ekstraksi $\mathrm{MeOH}$ terhadap flavonoid glikosida lebih kuat daripada EtOH, walaupun tidak cukup signifikan. Sementara itu metode refluks dengan temperatur yang lebih tinggi menunjukkan efektifitas yang lebih baik dibandingkan metode ultrasonikasi.<smiles>O=C(O)c1cc(O)c(O)c(O)c1</smiles>

1: $\mathrm{R}=\mathrm{H}$ (Gallic acid) 2: $\mathrm{R}=\mathrm{CH}_{3}$ (Methyl gallate)<smiles>O=c1oc2c(O)c(O)cc3c(=O)oc4c(O)c(O)cc1c4c23</smiles>

4 : Ellagic acid<smiles>[R2]c1c(-c2ccc(O)c(C)c2)oc2cc(O)cc(O)c2c1=O</smiles>

$5: \mathrm{R}=6$ - $O$-galloyl- $\beta$-D-glucopyranosyl (Astragalin 6"-O-gallate)

$7: R=\beta$-D-glucopyranosyl (Astragalin)

$8: R=\alpha-L$-arabinofuranosyl (Juglanin)

$3: \mathrm{R}=6-O$-galloyl $-\beta-\mathrm{D}$-glucopyranosyl (Isoquercitin $6^{\prime \prime}-O$-gallate)

$6: \mathrm{R}=\alpha-\mathrm{L}$-arabinofuranosyl (Avicularin)

Gambar 2 Struktur kimia delapan komponen polifenol yang teridentifikasi pada E. Supina. 


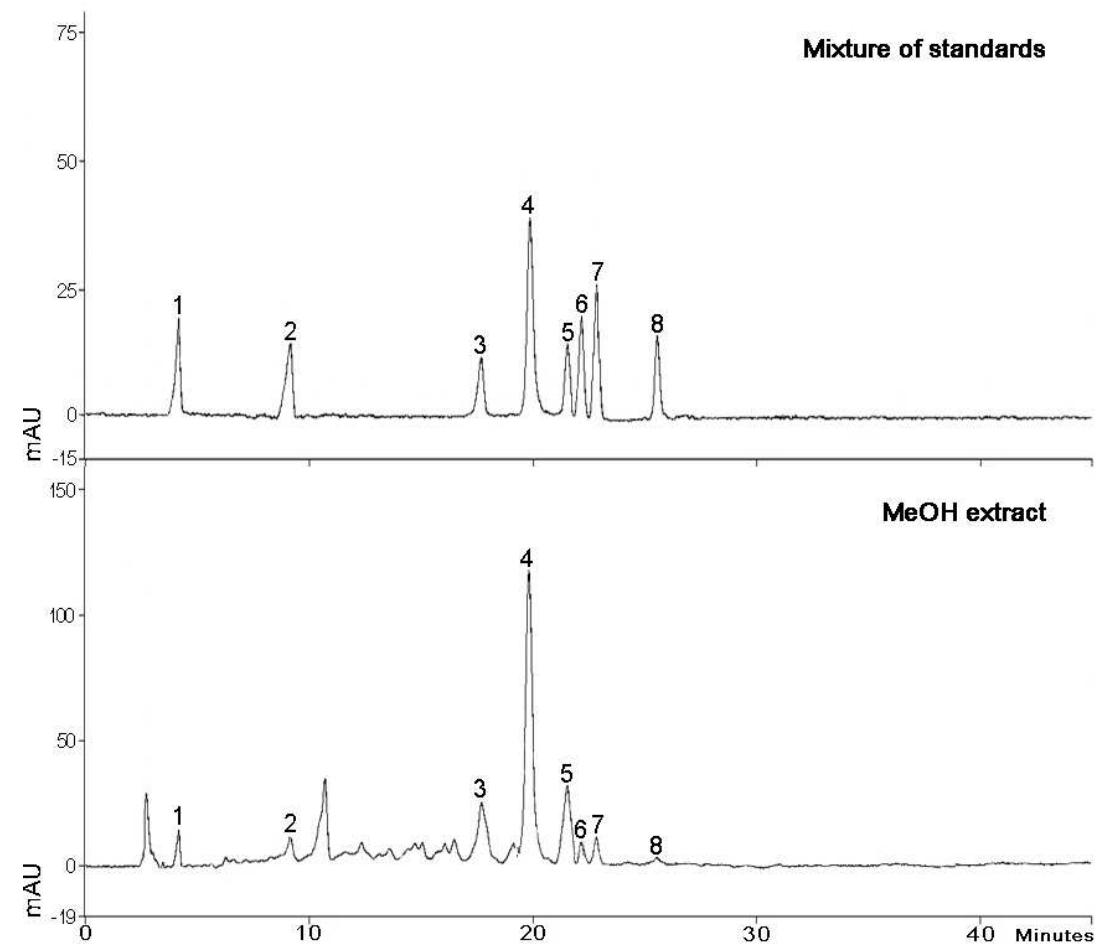

Gambar 3 Kromatogram HPLC dari delapan komponen standar serta keberadaannya pada ekstrak MeOH E. supina.

Tabel 2. Perbandingan konsentrasi delapan polifenol pada lima jenis ekstrak (mg/g) melalui ekstraksi ultrasonikasi

\begin{tabular}{cccccc}
\hline \multirow{2}{*}{$\begin{array}{c}\text { No. } \\
\text { Komp. }\end{array}$} & $\mathrm{MeOH}$ & EtOH & $\begin{array}{c}70 \% \\
\mathrm{MeOH}\end{array}$ & $\begin{array}{c}30 \% \\
\mathrm{MeOH}\end{array}$ & $\mathrm{H}_{2} \mathrm{O}$ \\
\hline $\mathbf{1}$ & 2.62 & 1.38 & 2.87 & 5.51 & 29.03 \\
$\mathbf{2}$ & 3.17 & 1.22 & 6.34 & 10.11 & 8.44 \\
$\mathbf{3}$ & 5.67 & 6.40 & 7.98 & 2.88 & 0.72 \\
$\mathbf{4}$ & 11.16 & 11.95 & 10.23 & 10.20 & 3.56 \\
$\mathbf{5}$ & 0.96 & 0.68 & 0.57 & n.d. & n.d. \\
$\mathbf{6}$ & 4.82 & 4.31 & 3.78 & 3.26 & 1.63 \\
$\mathbf{7}$ & 1.25 & 1.29 & 0.87 & 0.75 & 0.36 \\
$\mathbf{8}$ & 0.93 & 0.63 & 0.61 & 0.36 & 0.26 \\
\hline Total & 30.57 & 27.84 & 33.25 & 32.99 & 43.94 \\
\hline
\end{tabular}

\section{Analisis efisiensi ekstraksi}

Dari sudut pandang industri, efisiensi proses produksi menjadi poin penting yang selalu menjadi perhatian utama. Temuan teknologi akan layak untuk dapat diaplikasikan jika mampu memberikan nilai efisiensi yang lebih tinggi. Proses ekstraksi dengan metode ultrasonikasi dan refluks memiliki prinsip dasar yang sangat berbeda. Ultrasonikasi menggunakan prinsip getaran dengan frekuensi tinggi, sementara refluks melibatkan temperatur yang lebih tinggi, yaitu sesuai titik didih pelarut dengan disertai tekanan dari pelarut itu sendiri (Nugroho, 2017). Adanya proses pemanasan pada metode refluks, maka konsumsi energi menjadi lebih tinggi. Dengan teknologi yang lebih sederhana, biaya investasi metode refluks lebih rendah. Sementara itu dari sudut pandang efektifitas, metode refluks jauh lebih efektif dalam menghasilkan rendemen produk dua kali lebih tinggi dibandingkan ultrasonikasi pada penggunaan pelarut yang sama yaitu $\mathrm{MeOH}$ (Tabel 3 ).

Tabel 3. Perbandingan konsentrasi delapan polifenol pada ekstrak $\mathrm{MeOH}$ yang dihasilkan dari dua proses ekstraksi yang berbeda (ultrasonikasi dan refluks)

\begin{tabular}{ccc}
\hline \multirow{2}{*}{ No. Komp. } & \multicolumn{2}{c}{ Konsentrasi polifenol pada ekstrak $(\mathrm{mg} / \mathrm{g})$} \\
\cline { 2 - 3 } & Ultrasonikasi & Refluks \\
\hline $\mathbf{1}$ & 2.62 & 5.40 \\
$\mathbf{2}$ & 3.17 & 3.12 \\
$\mathbf{3}$ & 5.67 & 16.99 \\
$\mathbf{4}$ & 11.16 & 15.64 \\
$\mathbf{5}$ & 0.96 & 13.72 \\
$\mathbf{6}$ & 4.82 & 2.99 \\
$\mathbf{7}$ & 1.25 & 2.10 \\
$\mathbf{8}$ & 0.93 & 0.99 \\
\hline Total & 30.57 & 60.94 \\
\hline
\end{tabular}

Dilihat dari aspek jenis pelarut ekstraksi, nilai rendemen dari lima jenis ekstrak tidak berbeda signifikan (Tabel 2). Meskipun demikian, terdapat perbedaan yang signifikan mengenai jenis komponen atau selektifitas dari komponen yang terekstrak pada pelarut yang berbeda. Pelarut dengan konsetrasi $\mathrm{H}_{2} \mathrm{O}$ yang lebih tinggi menghasilkan selektifitas ekstraksi yang baik untuk komponen asam fenolik sederhana dengan berat molekul 
rendah, seperti gallic acid dan methyl gallate. Sementara itu, komponen dengan polaritas yang lebih rendah ditandai dengan struktur yang lebih kompleks dan berat molekul yang lebih tinggi terbukti akan lebih efektif dan selektif untuk diekstrak menggunakan pelarut dengan kandungan alkohol tinggi ( $\mathrm{MeOH}$ atau EtOH). Meskipun harga $\mathrm{H}_{2} \mathrm{O}$ jauh lebih rendah dibandingkan $\mathrm{MeOH}$ atau $\mathrm{EtOH}$, akan tetapi pada proses evaporasi yang merupakan proses ikutan setelah ekstraksi, biaya energi untuk proses evaporasi pelarut $\mathrm{H}_{2} \mathrm{O}$ jauh lebih tinggi disebabkan titik didihnya yang lebih tinggi dibandingkan $\mathrm{MeOH}$ atau $\mathrm{EtOH}$. Pada konteks ini, pelarut $\mathrm{MeOH}$ atau EtOH lebih efisien. Selain itu, proses ekstraksi dapat menggunakan pelarut hasil siklus kondensasi.

\section{Penentuan tipe pelarut dan proses ekstraksi}

Selain faktor efisiensi, pemilihan tipe pelarut dan metode ekstraksi juga mempertimbangkan selektifitas ekstraksi terhadap komponen tertentu, terutama komponen dengan aktivitas biologis yang lebih baik. Berbagai laporan menunjukkan bahwa ellagic acid memiliki aktivitas biologis yang lebih kuat daripada gallic acid. Beberapa jenis flavonoid juga menunjukkan aktivitas antioksidan yang lebih kuat daripada asam askorbat (vitamin C) yang merupakan antioksidan yang paling dikenal dan telah digunakan secara komersial (Hong et al., 2013; Liu et al., 2009; Braca et al., 2002). Pada aspek ini, tentu saja pelarut $\mathrm{MeOH}$ dan $\mathrm{EtOH}$ lebih efektif dan selektif untuk menarik komponen-komponen dengan kriteria tersebut.

Dari aspek toksisitas dan aspek lingkungan pelarut $\mathrm{EtOH}$ memiliki toleransi yang lebih baik dibandingkan $\mathrm{MeOH}$. Dengan efektifitas yang tidak jauh berbeda, serta dengan mempertimbangkan aspek toksisitas dan lingkungan, pelarut EtOH lebih prospektif daripada $\mathrm{MeOH}$. Sementara itu dari segi tipe proses, ekstraksi refluks dinilai lebih efektif dan efisien dibandingkan metode ultrasonikasi.

\section{Kesimpulan}

Metode ekstraksi refluks dengan pelarut EtOH mampu memberikan kinerja ekstraksi yang lebih baik ditinjau dari aspek efektifitas, efisiensi, selektifitas, serta aspek toksisitas dan toleransi terhadap lingkungan. Metode refluks menunjukkan efektifitas dua kali lebih baik dibanding ultrasonikasi. Pelarut alkohol lebih selektif dalam mengekstrak komponen dengan aktivitas biologis yang lebih kuat.

\section{Referensi}

Babujanarthanam R., Kavitha P., Pandian M.R., Quercitrin, A (2010) Bioflavonoid improves glucose homeostasis in Streptozotocin-induced diabetic tissues by altering glycolytic and gluconeogenic Enzymes, Fundamental and Clinical Pharmacology 24 (357-364).

Braca A., Sortino C., Politi M., Morelli I., Mendez J (2002) Antioxidant Activity of Flavonoids from Licania licaniaeflora, Journal of Ethnopharmacology, 79 (379-381).

Camalada M., Camuesco D., Sierra S., Ballester S., Xaus J., Galvez J., Zarzuelo A (2005) In vivo Quercitrin AntiInflammatory Effect Involves Release of Quercetin, which Inhibits Inflammation through DownRegulation of the NF-kB pathway, European Journal of Immunology 35 (584-592).

Farmakope Indonesia Edisi V, Kementerian Kesehatan Republik Indonesia, 2014.

Hong C.O., Lee H.A., Rhee C.H., Choung S.Y., Lee K.W (2013) Separation of the antioxidant Compound Quercitrin from Lindera obtusiloba Blume and Its Antimelanogenic Effect on B16f10 Melanoma Cells, Bioscience, Biotechnology, and Biochemistry 77 (5864).

Huang L., Chen S., Yang M (2012) Euphorbia hirta: A review on its ethnopharmacology, phytochemistry and pharmacology, Journal of Medicinal Plants Research 6 (5176-5185).

Liu Q, Zhang Y.J., Yang C.R., Xu M (2009) Phenolic Antioxidants from Green Tea Produced from Camellia crassicolumna var. Multiplex, Journal of Agricultural and Food Chemistry, 57 (586-590).

Nugroho A., Lim S.C., Choi J., Park H.J (2013) Identification and Quantification of Sedative and Anticonvulsant Flavone Glycoside from Chrysanthemum boreale, Archive of Pharmacal Research, 36 (51-50).

Nugroho A (1996) Teknologi Bahan Alam, Lambung Mangkurat University Press, Banjarmasin, 2017.

Smallwood I.M., Handbook of Organic Solvents Properties, Arnold, London. 